\title{
ZNAČAJ NARODNIH BIBLIOTEKA U PROCESIMA EMANCIPACIJE I OSNAŽIVANJA ŽENA NA PRIMJERU RADA MUSLIMANSKE NARODNE BIBLIOTEKE U MOSTARU U PERIODU OD 1936. DO 1941. GODINE
}

\author{
Ajla Demiragić* \\ ajla.demiragic@ff.unsa.ba \\ Arijana Bajrić* \\ arijanabajric@gmail.com \\ * Odsjek za komparativnu književnost i bibliotekarstvo, Filozofski fakultet Univerziteta u Sarajevu, Sarajevo, Bosna i \\ Hercegovina \\ Department of Comparative Literature and Library Sciences, Faculty of Philosophy, University of Sarajevo, Sarajevo, \\ Bosnia and Herzegovina
}

\begin{abstract}
Sažetak
U prvoj polovini 20. stoljeća upravo će narodne biblioteke i čitaonice imati iznimno važnu ulogu u procesima promoviranja progresivnih ideja i obrazovanja širih slojeva društva, te će svojim radom osigurati temeljne preduvjete cjelokupne društvene i kulturne transformacije bosanskohercegovačkog društva. Pored ostalog, pojedine narodne biblioteke bit će iznimno važni akteri u procesima osnaživanja, emancipacije i edukacije žena, a njihove čitaonice nerijetko i jedini javni prostor za razmjenu iskustva i sudjelovanja u društveno korisnim aktivnostima. U radu su predstavljene aktivnosti koje su se realizirale u okviru Muslimanske narodne biblioteke u Mostaru u periodu od 1936. do 1941. godine, a koje su omogućile ženama ne samo da uspješno završe analfabetske tečajeve, već i da sudjeluju u obuci i edukaciji drugih žena. Njihov angažman u biblioteci osigurat će da mnoge od njih postanu članice antifašističkog pokreta otpora tijekom rata i aktivne sudionice u procesima poslijeratne obnove i izgradnje modernog bosanskohercegovačkog društva.
\end{abstract}

Ključne riječi: narodne biblioteke, Muslimanska narodna biblioteka u Mostaru, analfabetski tečajevi Muslimanske narodne biblioteke, emancipacija žena

\section{Uvod}

Već koncem 70-ih godina prošlog stoljeća, u znanstvenim krugovima na Zapadu pokrenute su rasprave o nevidljivosti žena ili njihovoj nedovoljnoj zastupljenosti u povijesnim prikazima razvoja pojedinih profesija, odnosno propustima u vezi nedokumentiranja aktivnosti žena zbog navodnog nedostatka povijesnih izvora. Na prostoru bivše Jugoslavije prve takve rasprave bilježe se sredinom 80-ih godina 20. stoljeća. Nažalost, u Bosni i Hercegovini takve debate ostale su na početnoj razini. I danas je veliki broj činjenica o povijesnoj djelatnosti žena, njihovom angažmanu i doprinosu unutar mnogih profesija ostao nepoznat ili vrlo slabo istražen. To je slučaj čak i s onim profesijama koje se već duže vrijeme određuju i percipiraju kao "ženske".
Bibliotekarstvo je već duži vremenski period profesija kojom dominiraju žene, kako na nižim, tako, sve češće, i na rukovodećim pozicijama, ali i u okviru znanstvenoistraživačkih akademskih centara. No, kod nas, ali i šire u regionu, još uvijek nisu pokrenute inicijative u pravcu artikuliranja orodnjene povijesti bibliotekarstva, onako kako ju je u kontekstu SAD-a zagovarala, između ostalih, Suzanne Hildenbrand (1992; v. i Weibel et al. 1979; Heim 1983; Hariss 1992; Garisson 2003). U tom kontekstu treba istaći da "uključivanje feminističkog naslijeđa $\mathrm{u}$ bibliotekarstvo jeste put ka afirmaciji njegovog subverzivnog karaktera čije emancipatorne geste izazivaju institucionalizirane vrijednosti i upućuju na značaj njihova revaloriziranja" (Demiragić, Hibert 2017, 69). 
Na tragu feminističkih strategija ponovnog 'otkrića' žene i 'ženskih masa' kao djelatnog čimbenika povijesnih procesa (usp. Sklevicky 1996, 20), nakana ovog rada jeste da pokuša, na primjeru angažmana žena i njihovog osnaživanja u okviru Muslimanske narodne biblioteke u Mostaru, u periodu od 1936. do 1941. godine, da reinterpretira ulogu i doprinos jedne kulturne javne institucije kakva je narodna biblioteka koristeći rod kao analitičku kategoriju. Ujedno, opisujući rad Muslimanske narodne biblioteke u naznačenom periodu, pokušat će se istaknuti uloga biblioteke kao svojevrsnog instrumenta društvenih promjena, mjesta uspostave novih društvenih veza i solidarnosti (usp. Hibert 2018, 119).

\section{Povijesni kontekst i razvoj narodnih biblioteka u BiH u periodu između Prvog i Drugog svjetskog rata}

U periodu nakon Prvog svjetskog rata i sloma Austro-Ugarske Monarhije, Bosna i Hercegovina će ući u sastav novoformirane Kraljevine Srba, Hrvata i Slovenaca, koja će 1929. godine biti preimenovana u Kraljevinu Jugoslaviju. Kako navodi Ljubinka Bašović (1986, 15), položaj biblioteka i općenito bibliotekarstva u Bosni i Hercegovini, koja će od 1929. biti podijeljena u četiri banovine, u ovom periodu obilježen je "nepostojanjem planskog, smišljenog i sistemskog rada". Slična situacija je bila i u ostalim dijelovima Kraljevine. Tako su, primjerice, i u Hrvatskoj teška ekonomska kriza, nedostatak zakonske regulative i finansijska dioba doveli do vrlo teškog stanja u okviru bibliotečke djelatnosti u međuratnom periodu (v. više u Švenda-Radeljak 2018). Država se preko Ministarstva prosvjete i banovinskih vlasti prvenstveno bavila nadzorom nad bibliotečkom djelatnošću i izdavanjem propisa za poslovanje, dok je materijalna pomoć ostala simbolična, budući da je finansijska potpora samo jednim dijelom bila predviđena za školske, specijalne, centralne državne i opštenaučne biblioteke (usp. Bašović 1986, 16).

U skladu s tim, u navedenom periodu konkretne inicijative za uspostavljanje ili poboljšavanje osnovnih bibliotečkih usluga, osnivanje narodnih biblioteka i podupiranje njihovog rada u pravilu su pokretala kulturno-prosvjetna i konfesionalna društva, profesionalne asocijacije i pojedinici koji su bili svjesni važnosti biblioteka za razvoj i napredak zajednice u cjelini. Usprkos činjenici da ovaj tip biblioteke nije finansirala država, one su često bile puno efikasnije i ostvarivale više rezultata u svom radu od onih javnih (ibid).

Narodne biblioteke bile su posebno namijenjene radnicima, seljacima, zanatlijama, odnosno svima koji su bili deprivilegirani u buržoaskom društvu (usp. Mesić 1991, 151). Inače, prve narodne (javne) biblioteke osnivaju se u SAD i Velikoj Britaniji sredinom 19. stoljeća kao posljedica industrijalizacije i jačanja borbe za radnička prava i poboljšavanje životnih uvjeta radnika. Na našem prostoru, prve narodne biblioteke pokreću se koncem 19. i početkom 20. stoljeća. Pod utjecajem Oktobarske revolucije i Lenjinovih postavki o kulturnoj revoluciji, od sredine tridesetih godina 20. st. dolazi do procvata narodnih biblioteka koje djeluju u sklopu revolucionarnog radničkog pokreta i progresivnih društava. Ove biblioteke posebnu pažnju poklanjat će obrazovanju odraslih i idejno usmjerenom političkom i kulturno-prosvjetnom odgoju čitatelja/ica (usp. Bašović 1986, 15). Ujedno, vodeći računa o vrlo nepovoljnim ekonomsko-kulturnim prilikama u društvu, posebice o velikom procentu nepismenog stanovništva i iznimno teškim životnim uvjetima djevojčica i žena, ove će biblioteke odigrati vrlo važnu ulogu u procesima edukacije i emancipacije žena. Narodne biblioteke i čitaonice će biti jedan od najvažnijih javnih prostora političkog i profesionalnog osnaživanja žena u Bosni i Hercegovini u međuratnom periodu. $\mathrm{Na}$ primjeru Muslimanske narodne biblioteke u Mostaru, u nastavku rada pokušat će se prikazati uloga i značaj ovog tipa biblioteke u procesima društvenog osnaživanja žena. S druge strane, ovaj rad pledira za pokretanje sistematskih istraživanja i preispisivanja povijesti bibliotekarstva na ovim prostorima i iz rodne perspektive

\section{Muslimanska narodna biblioteka u Mostaru u periodu od 1928. do 1936. godine}

Muslimansku narodnu biblioteku u Mostaru (isprva Muslimanska javna biblioteka) osniva grupa mladića, maturanata mostarske Gimnazije, na ljeto 1928. godine. Grupu je predvodio Fuad Slipčević, osnivač i predsjednik, a inicijativni odbor su sačinjavali: Fuad Slipčević, Fazlija Alikalfić, Salko Humo i Salih Ćišić (usp. Bašović 1986, 122). Prvobitna namjera je bila da biblioteka omogući ubrzavanje procesa prosvjećivanja muslimana na prostoru Mostara i okoline. Po mišljenju Ljubinke Bašović, rad biblioteke može se podijeliti u dvije faze. Prvu fazu obuhvata period od osnivanja do 1936. godine, a druga faza traje od 1936. godine pa do prisilnog zatvaranja biblioteke, uspostavom Nezavisne Države Hrvatske u aprilu 1941. godine.

U periodu od 1929. do 1935. godine biblioteka će djelovati u okviru muslimanskog kulturno-prosvjetnog društva Gajret, a početkom 1930. godine bit će usvojena i odluka o izmjeni naziva u Gajretovu narodnu biblioteku. Bitno je istaknuti da je biblioteka i u ovom periodu sačuvala samostalnost i da nije postala dijelom ranije uspostavljenih institucija Gajreta. U prvoj fazi rada, biblioteka je uspjela da pokrene analfabetske tečajeve i popularizira čitanje knjiga među širim narodnim slojevima, posebice 
među mostarskom omladinom, a ujedno je osigurala i stalni porast kako knjižnog fonda tako i broja čitatelja/ica. (usp. Bašović 1986, 123)

U okviru druge faze rada, Biblioteka postaje "organizacija koja se bavi kulturnim, prosvjetnim i političkim vaspitavanjem građanstva" (Alikalfić 1971, nav. prema Bašović 1986, 122). Kao jedan od glavnih razloga za preokret u orijentaciji i djelovanju ove biblioteke navodi se zabrana rada studentskim udruženjima na prostoru Bosne i Hercegovine 1936. godine. Ova zabrana dovest će do toga da će Biblioteka postati mjesto okupljanja i organiziranja napredne inteligencije, studenata i srednjoškolske omladine. Na skupštini koja se održala 5. i 6. 2. 1936. godine, u upravni odbor Biblioteke ušli su komunisti i progresivno orijentirani intelektualci (usp. Bašović 1989, 123-124). Tijekom 1938. godine dolazi do izmjena u pravilima rada i biblioteka je ponovo preimenovana, ovaj put u Muslimansku narodnu biblioteku. Sve do početka Drugog svjetskog rata i prestanka zvaničnog rada, ova biblioteka će kontinuirano unapređivati svoj rad. Bilježit će stalni porast broja svezaka, kao i stalnih članova/ ica. Pored ostalog, u njenim prostorijama održavat će se kružoci za izučavanje marksističke literature, instrukcije za učenike srednjih škola te javna predavanja iz različitih znanstvenih oblasti i godišnje zabave. Biblioteka je imala i svoju muzičku sekciju, a posebno važan doprinos bio je njen rad u selima u okolini Mostara (usp. Bašović 1989, 126).

\section{Od emancipacije do aktivne participacije žena}

Kako Jovanka Kecman (1978) navodi u prvoj studiji o profesionalnom angažmanu žena u okviru radničkog pokreta i ženskih organizacija na prostoru bivše Jugoslavije, ukupni podaci o stanju pismenosti u Kraljevini Jugoslaviji ukazivali su na slabi napredak u periodu od 1931. do 1941. Tako je prema podacima školske 1938/39. godine obaveznim školovanjem bilo obuhvaćeno svega 33,3\% od ukupnog broja ženskog stanovništva. U Bosni i Hercegovini taj procenat je bio dosta niži i iznosio je 19,8\% (usp. Kecman 1978, 25). Osim što se broj nepismenih žena i dalje povećavao, jedan od ključnih problema, riječima Jovanke Kecman, sastojao se u sljedećem:

Učenice koje su završile obaveznu četvorogodišnju osnovnu školu, s relativno malim brojem izuzetaka, nisu nastavljale dalje školovanje. U uslovima opšte kulturne zaostalosti i ekonomske nerazvijenosti zemlje, one uglavnom nisu imale mogućnosti da se zapošljavaju i proširuju svoje obrazovanje. Naprotiv, vremenom su gubile ono elementarno znanje iz osnovne škole. Usled takvog stanja žene su, pogotovo na selu, bile isključene iz društvenog života i rada. (ibid)
U posebno nepovoljnoj poziciji u tom smislu nalazile su se žene muslimanke. Naime, iako je od kraja Prvog svjetskog rata došlo do izvjesnih pomaka po pitanju školovanja muslimanki ${ }^{1} \mathrm{u}$ obrazovnim ustanovama Kraljevine Jugoslavije, povjesničar Adnan Jahić $(2017,343)$ smatra da je broj učenica ostao u "simboličkom omjeru spram ukupnog broja bošnjačkog ženskog stanovništva". Kako navodi Jahić, pozivajući se na podatke Ulema-medžlisa iz 1931. godine, ukupan broj muslimanki koje su pohađale građanske i srednje škole u Bosni i Hercegovini iznosio je 607, odnosno 0,16\% ukupnog broja žena u pokrajini (usp. ibid).

Da bi se bar donekle ublažio ovaj negativni trend, u Mostaru se 1919. godine osniva Muslimanska ženska zadruga, koja je trebala da omogući stručno obrazovanje, vaspitanje i podupiranje muslimanki. U okviru zadruga organizirali su se tečajevi krojenja i šivanja, a osam mjeseci nakon uspostave Zadruge uspješno je organiziran i prvi analfabetski tečaj, tri tečaja za krojenje, te zaposleno i petnaest stalnih učenica. Ujedno je uređena i mala biblioteka za članice Zadruge (nav. prema Jahić 2017, 168-169). Pored Zadruge, u Mostaru je radio i Gajretov ženski konvikt, a na inicijativu Gajreta otvorena je i Domaćinska škola, koja je svake godine držala petomjesečne tečajeve iz domaćinstva koje je pohađalo i upješno završavalo između 25 i 30 muslimanskih djevojaka (nav. prema Hasandedić 2001, 203). ${ }^{2}$ Istovremeno, kulturno-prosvjetno društvo Gajret imalo je ženske odbore u svojim mjesnim odborima, a u Mostaru je takav odbor formiran već 1919. godine. U odboru su, tokom godina, radile: Muruveta Alajbegović, Fikreta i Enesa Behlilović, Ferida Jahić, Mukelefa Ugljen, Kajdefa Efica, Ulfeta i Hašmeta Arpađić, Šefika Hadžić, Ziba Kapetanović, Šemsa Kajtaz, Ćamila Nožić, Azema Mrkonjić, Sidika Omeragić, Zejna Drače, Atifa Kurt, Fahra Milavić, Rahma Vrgora, Šerifa Koluder, Hatidža Ćišić, Šefika Ševa i druge (nav. prema prema Hasandedić 2001, 202). Ovi odbori isprva su okupljali žene koje su sudjelovale u organizaciji zabava i priredbi na kojima su se prikupljali dobrovoljni prilozi za prosvjetne svrhe Gajreta (usp. Jahić 2017, 227). Kasnije će se žene iz ovih odbora snažnije okupiti oko Muslimanske javne biblioteke i tečajeva koje će biblioteka organizirati, a sve u cilju opismenjavanja, obrazovanja i obučavanja muslimanki za život $\mathrm{u}$ aktuelnom trenutku.

1 Tijekom 1929. godine na prostoru Kraljevine Jugoslavije bit će uvedeno obavezno obrazovanje djece do četrnaest godina, što će nužno dovesti do porasta broja muslimanske djece u obrazovnom sustavu, posebice porasta broja djevojčica u periodu između 1928. i 1937. godine. Usprkos ovim mjerama, broj nepismenih muslimanki na prostoru BiH ostat će do kraja 1939. godine izuzetno visok i iznosit će preko $87 \%$ (nav. prema Spahić et al. 2014)

2 O radu i aktivnostima Gajreta vidjeti više u: Kemura 1986. 
U okviru prve faze rada, Muslimanska javna biblioteka, odnosno Gajretova narodna biblioteka, nastojat će da ponudi svoj doprinos u borbi za kulturnu, prosvjetnu i ekonomsku emancipaciju žena. Biblioteka postaje mjesto gdje se organiziraju analfabetski tečajevi za muslimanke. Tako se već 1929. godine, od 1. juna do 1. septembra, organizira tečaj na kojem su predavači bili sljedeći učitelji/ce: Husnija Kapić, Ibrahim Grčić, Salema Salahović, Hakija Raljević i Hamdija Fazlinović. Od 35 upisanih polaznica ovog tečaja, ispitu je pristupilo njih 25. Opći uspjeh ispita bio je vrlo dobar. Pored tečaja, održavana su predavanja s najraznovrsnijim aktuelnim temama. O tome koliko je pažnje u tim aktivnostima posvećivano ženama, govori i tema jednog od predavanja koje je 1930. godine držao Fuad Slipčević, tada student filozofije: Feminizam i muslimanska žena.

Gajret je imao i svoj pjevački hor koji je na Bajrame, a i prilikom nekih drugih svečanosti priređivao koncerte, čajanke i zabave u Mostaru, Blagaju i Bijelom Polju, na kojima su se izvodili pozorišni komadi, igrala tombola i birala kraljica ljepote. O tome koliko su zabave bile posjećene govori i podatak da je na jednoj takvoj zabavi za najljepšu damu zabave izabrana gđica Hiba Duvnjak s 412 glasova (nav. prema List Gajret 1929, 310). Ove muzičke i pozorišne sekcije naročito su se razvile u kasnijem radu biblioteke

Sve navedene aktivnosti približile su Biblioteku ženama, tako da su se one sve više vezale za ovu instituciju kao mjesto svog usavršavanja i društvene interakcije. Pored stalnog članstva, žene dobijaju priliku da postanu i članice odbora Biblioteke. Za prve odbornice biraju se: Aiša Čevro, Zarifa Kurt i Hatidža Hadžiosmanović.

No, tek će u drugoj fazi rada Biblioteke doći do radikalnog zaokreta u radu sa ženama i do cjelovite transformacije društvene uloge žene u programima ove institucije. Kao što je ranije istaknuto, zbog zabrane studentskog udruživanja, ali i povratka osnivača Biblioteke sa studija, 1936. godine dolazi do preokreta u njenom radu i organizaciji. Idejni tvorci i osnivači Biblioteke smatrali su da, u teškoj političkoj i ekonomskoj situaciji u zemlji i svijetu, ta institucija mora raditi više i bolje. Na skupštini održanoj 9. 2. 1936. godine, u prostorijama Muslimanskog kluba, za sekretara Biblioteke izabran je Fazlija Alikalfić, a u odbor je ponovo ušao prof. Hasan Ćišić, uz još neke ugledne intelektualce i građane Mostara. Na skupštini su donijeli i zaključke o organizaciji i radu Biblioteke. Po mišljenju članova odbora bilo je potrebno što prije organizirati Biblioteku na modernoj bazi, stvaranjem kartoteke i sistema reversa, razviti plansku akciju za čitanje korisnih knjiga kod širih slojeva građanstva, naročito kod žena, pokrenuti dvanaestomjesečne tečajeve za žene počevši od novembra 1936. godine i što skorije pokrenuti akcije za proučavanje prilika na selu (prema Ćišić 1937, 96).

Kao što je vidljivo iz gore navedenih zaključaka novouspostavljenog odbora Biblioteke, rad sa ženama bio je od prioritetnog značaja. O ozbiljnosti rada Biblioteke ponajbolje govori podatak o tečaju za žene koji je organiziran u planiranom periodu novembar 1937. - maj 1938. godine, kao šestomjesečni tečaj, a koji su vodili srednjoškolski profesori, ljekari, inžinjeri i učitelji narodnih škola. Kako bi uskladili program, svaki od njih je izradio plan gradiva koje će se izučavati. Program tečaja sastojao se od sljedećih tema i predmeta: "1) srpskohrvatski jezik (prof. H. Čisić), 2) osnovi praktične hemije (prof. H. Kurt), 3) osnovi praktične fizike (prof. S. Ćisić), 4) osnovi biologije, zoologije i botanike (prof. S. Baljić), 5) osnovi higijene, posebno higijene žene, osnovi fiziologije i anatomije (dr. S. Mujić), 6) osnovi matematičkog zemljopisa (prof. H. Čisić), 7) osnovi opšteg zemljopisa (učitelj S. Fehimović) 8) osnovi opšte istorije (prof. M. Alikalfić), 9) osnovi geologije (ing. Č. Ugljen), 10) osnovi mineralogije i paleontologije (ing. F. Alikalfić)" (Ćišić 1937, 97). Predavanja su se održavala u sali Osnovne škole "Kraljica Marija", a po potrebi i u kabinetima za fiziku i hemiju gimnazije. U kino sali Zajednice doma i škole davali su se razni poučni filmovi vezani za nastavni plan tečaja. Filmove je ustupilo Prosvjetno odjeljenje Banske uprave u Splitu preko mostarskog Doma narodnog zdravlja. Predavanja su održavana tri puta sedmično po dva časa. U nastavi su upotrebljavane najsavremenije metode tog doba i korištena sva potrebna pomagala. Svakom času prisustvovali su dežurni članovi uprave, koji su kontrolirali rad predavača. Broj polaznica tečaja kretao se između 75 i 110 po predavanju. Naravno, mnoge od njih su prisustvovale većem broju predmeta koji su se izučavali, pa to nije stvarni broj polaznica ovog tečaja, ali je to i dalje za to vrijeme zavidan broj žena koje su imale priliku dobiti tako široku naobrazbu u tako kratkom roku (nav. prema Ćišić 1937, 97).

Kako je i planirano na sjednici odbora Biblioteke, održan je i drugi tečaj u periodu novembar 1938. - maj 1939. godine. Na tom tečaju izučavali su se “1) književnost naša i strana (potreba i vještina čitanja s primjerima), 2) dalje o opštem zemljopisu i zemljopisu kraljevine Jugoslavije, 3) dalje o opštoj istoriji i istoriji Južnih Slavena - poseban osvrt na istoriju Bosne i Hercegovine, 4) dužnosti i prava žene u Islamu, njen socijalni položaj, 5) najvažnije grane domaćinstva, 6) njega i odgoj djece; zaštita djece, 7) organizacija jedinica u radu za narod od strane slušateljica tečaja, čemu se posvetila naročita pažnja" (Čišić 1937, 97). Ovaj šestomjesečni tečaj nije završen uobičajenim ispitom. Svi nedostaci ovog tečaja, poput nedostatka udžbenika, isprav- 
ljeni su u narednom ciklusu edukacije, nakon kojeg je uslijedio svečani javni ispit u maju naredne godine. Kako bi se i praktično provjerilo stečeno znanje polaznica tečaja, Upravni odbor Biblioteke organizirao je i ekskurziju u Dubrovnik. Cilj je bio upoznati žene s kulturno-povijesnim naslijeđem te im pokazati i parobrod. Biblioteka je organizirala i ekspediciju u neka od najzaostalijih sela u okolini Mostara, u Podveležju, i tom prilikom ustanovljeno je da je samo jedan žitelj tih sela bio pismen. Cilj ekskurzije bio je da se što bolje upoznaju prilike i uslovi života na selu kako bi u narednom periodu Biblioteka mogla da djeluje u pravcu unapređenja životnih uvjeta ruralnog stanovništva tog kraja (nav. prema Čišić 1937, 97).

Pored analfabetskih tečajeva i predavanja, svake godine održavala se i godišnja zabava kao svojevrsna prezentacija svega što je Biblioteka postigla $u$ okviru jedne godine. Bile su to posebno pripremane predstave s jasnim porukama (poput drama "Oslobađanje Koste Šljuke ili "Voda s planine") koje su izvodili najbolji i najpoznatiji glumci i muzičari iz Mostara i Jugoslavije (usp. Bašović 1986, 126).

Članovi/ce Biblioteke su prema posjećenosti zabava procjenjivali svoj uticaj na građane/ke Mostara. Pored zabava, subotom i nedjeljom bila su upriličena i druženja u prostorijama Biblioteke, gdje su održavane klupske večeri s kulturno-zabavnim programom. Posjećenost je bila velika, pa su prostori kluba renovirani i prošireni dva puta.

U posljednjim godinama rada Biblioteka je svoje djelovanje, u skladu sa zacrtanim ciljevima, proširila i na okolicu Mostara, pokušavajući dobru praksu institucije prenijeti i na selo, prije svega Blagaj, Bijelo polje, ali i ranije spomenuto Podveležje. U tim akcijama sudjelovali su članovi/ce Biblioteke te školovani ljudi, ljekari, inžinjeri, agronomi, pravnici, ali i svi oni koji su na bilo koji način svojim znanjem i radom mogli pomoći u rješavanju nekog pitanja ili problema (usp. Bašović 1986, 125).

Upravo će se u posljednjim godinama rada Biblioteke stvoriti uvjeti da se žene istaknu ne samo kao polaznice tečajeva već i kao vrlo marljive djelatnice biblioteke. U upravu Biblioteke po prvi put bit će izabrano i nekoliko žena: Hatidža Brkić, Nazika Mrgan, Šefika Resulbegović i Naza Mrkonjić. Pored njih, u komisijama su surađivale i intelektualke koje su živjele i radile u Mostaru: prof. Dragica Krnić i Mara Zuber, Elza Hanzeković, sutkinja Okružog suda Nadžida Hadžić-Novak i druge (nav. prema Konjhodžić 1981, 36). Pošto je rad Biblioteke bio posebno pogodan za žene, osnovan je i Ženski odbor, koji je pripremao nove oblike masovnog rada sa ženama. Kako navodi Mahmud Konjhodžić:

Za vrlo kratko vrijeme je ženska omladina, od koje je više od stotinu djevojaka završilo srednje obrazovne tečajeve sa zapaženim uspjehom, postala najagilniji dio članstva biblioteke. Od učenica srednjih škola, domaćica i radnica koje su se tako školovale postale su prve mlade javne radnice. Tako je $\mathrm{u}$ sastavu biblioteke radilo dosta djevojaka koje su se isticale i znanjem i plemenitim nastojanjima kao što su bile Zlata Salahović, Hatidža Udovičić, Asija Ridžanović, Bisera Puzić, Fadila Bilal, Kevser Tikvina, Ljubica Mihić, Aiša Udovičić, Fahra Fejić, Samija Behlilović i mnoge druge. One su postale stubovi rada biblioteke na svim područjima. (Konjhodžić 1981, 38)

Zbog ovakve orijentacije u radu sa ženama, Biblioteci su povremeno upućivani oštri prigovori, a najviše negodovanja je dolazilo upravo zbog brzog i masovnog uvođenja žena u program i rad Biblioteke. Na ove prigovore članovi/ce Biblioteke odgovarali su pozivom na javne razgovore, a rado su surađivali i s društvima koja su promovirala drugačije svjetonazore. Tako su primjerice s muslimanskim društvom Ihvan, koje je okupljalo konzervativne i religiozne intelektualce Mostara, organizirali predavanja o temama iz islamske etike, morala i tradicije. U svega nekoliko godina, zahvaljujući radu u okviru Biblioteke i prilici za stručno usavršavanje, žene Mostara su prešle dugi put od emancipacije do osviještenih i pasioniranih političkih aktivistica. Pred sam početak rata sudjelovale su u nekoliko akcija koje će Biblioteka organizirati s ciljem spašavanja barem jednog dijela knjižnog fonda. Naime, nakon Sporazuma Cvetković-Maček 1939. godine novoformirana vlast u banovini donijela je odluku o zabrani rada Biblioteke, a ustaški organi vlasti zapečatit će Biblioteku. U akcijama spašavanja knjiga iz zapečaćene Biblioteke bit će spašeno oko 1000 knjiga koje su raspoređene po sigurnim kućama u pojedinim dijelovima grada (nav. prema Bašović 1986, 127). Jednu od akcija prenošenja knjiga u kuću Jusufa Čevre u Donjoj Mahali i u kuću Hajrudina Puzića u Zahumu, osmislit će i predvoditi studentica Bisera Puzić, jedna od najaktivnijih članica Biblioteke (usp. Alikalfić 1985, 95). Od samog početka rata aktivno će učestvovavati u formiranju partizanskih odreda širom Hercegovine, a bit će izabrana i u Mjesni komitet Komunističke partije. Nakon rata Bisera Puzić, udata Taušan, postat će sutkinja Ustavnog suda u Sarajevu. Mnoge druge članice Biblioteke tokom rata sudjelovat će u pokretu otpora i dati ogroman doprinos narodnooslobodilačkoj borbi. O nemjerljivom doprinosu žena iz Mostara ponajbolje svjedoči podatak da je čak njih šezdeset i osam poginulo u borbama tokom Drugog svjetskog rata (usp. Salahović-Grebo, 2005). 


\section{Umjesto zaključka}

Knjige koje su prikupljane s puno ljubavi i truda od osnivanja Biblioteke pa sve do početka okupacije, a koje su ostale u zapečaćenoj Biblioteci, pripadnici ustaške vlasti spalili su na gradskom trgu Musala kao "kao simbol komunističke kuge" u julu 1941. godine (usp. Bašović 1986, 127-128). No, jedan dio knjiga Muslimanske narodne biblioteke koje su spašene i sačuvane tijekom Drugog svjetskog rata poslužit će kao početni fond novoosnovane Narodne biblioteke u Mostaru nakon rata (ibid). Muslimanska narodna biblioteka svojim djelovanjem $\mathrm{u}$ cijelosti je ispunila jednu od temeljnih zadaća - da bude istovremeno instrument "prosvjećivanja društva (fiat lux) i prostor za skrovištenje svjetla koje treba doći sutra (fiat latebra)" (Donald Krummel 1999, cit. prema Hibert 2018, 118).

Kroz prikaz aktivnosti i rada Muslimanske narodne biblioteke u Mostaru u ovom radu pokušale smo da ponovo ispišemo dio naše, danas već dobrim dijelom zaboravljene prošlosti, a s ciljem afirmiranja zanemarenih oblika javnog, odnosno društveno-politič- kog djelovanja žena na prostoru Bosne i Hercegovine. Na tragu tvrdnje Jamesa Thompsona da su javne biblioteke moćan pokretač društvenih i političkih promjena, ali istovremeno i čuvari slobode mišljenja $\mathrm{i}$ istinske tvrđave slobode (nav. prema Vučković 2003,50 ), ovaj rad ujedno poziva na to da se stalno nanovo promovira važnost javnih biblioteka i čitaonica kao prostora interakcije i razmjene mišljenja, ali i sigurnih zona susreta svih marginaliziranih i/ ili obespravljenih članova/ica društva. Istovremeno, prikazom aktivnosti Muslimanske narodne biblioteke usmjerenih na emancipaciju i osnaživanje žena koje su u periodu djelovanja Biblioteke trpile različite oblike diskriminacije i stigmatizacije, nastojalo se istaknuti još jednu bitnu dimenziju djelovanja javnih biblioteka i ukazati na važno povijesno iskustvo koje govori da one mogu biti mjesta socijalne uključenosti i profesionalne afirmacije. U mjeri $\mathrm{u}$ kojoj su problemi marginalizacije i diskriminacije žena, ali i drugih kategorija stanovništva, prisutni i danas, važna društvena uloga biblioteka još uvijek čeka svoju punu afirmaciju i aktueliziranje u bosanskohercegovačkom kontekstu.

\section{Literatura}

- Alikalfić, Fazlija. 1985. Stasanje jedne mladosti: Sjećanje na rad Muslimanske narodne biblioteke u Mostaru. Mostar: Skupština opštine - Odbor za organizaciju izrade priloga istoriji revolucionarnog ratničkog pokreta i NOB-e.

- Bašović, Ljubinka. 1986. Biblioteke i bibliotekarstvo u Bosni i Hercegovini, 1918-1945. Sarajevo: Veselin Masleša.

- Ćišić, Hasan. 1937. "Privatna inicijativa i narodno prosvjećivanje: Prosvjetni rad Gajretove narodne biblioteke u Mostaru" List Gajret 18(6): 96.

- Demiragić, Ajla, i Hibert, Mario. 2017. “Afirmativna sabotaža kontekstualnosti: o subverzivnom karakteru komparatistike i bibliotekarstva" U Život, narativ, sjećanje: prof. dr. Nirman Moranjak-Bamburać (1954-2007), uredili Almir Bašović, Ajla Demiragić i Marina Katnić-Bakaršić. Sarajevo: Filozofski fakultet.

- Garrison, Dee. 2003. Apostles of culture: The public librarian and American society, 1876-1920. Medison: Univ of Wisconsin Press.

- $\quad$ Harris, Roma M. 1992. Librarianship the Erosion of a Woman's Profession. Norwood, N. J.: Ablex Pub. Corp.

- Hasandedić, Hifzija. 2001. "Muslimanska društva u Mostaru. Muslim societies in Mostar" Anali Gazi Husrev-begove biblioteke 19-20: 197-214.

- Heim, Kathleen M., ur. 1983. The Status of Women in Librarianship: Historical, Sociological, and Economic Issues. New York, N. Y.: Neal-Schuman Publishers.

- Hibert, Mario. 2018. Digitalni odrast i postdigitalna dobra. Zagreb: Multimedijalni institut - Institut za političku ekologiju.

- Hildenbrand, Suzanne, ur. 1992. Reclaiming the American Library Past: Writing the Women In. Norwood, N.J.: Ablex Pub. Corp.

- Jahić, Adnan. 2017. Muslimansko žensko pitanje u Bosni i Herecegovini. Žene u intelektualnom i društvenom životu Bošnjaka od aneksije do Zakona o zabrani nošenja zara i feredže (1908-1950). Zagreb: Bošnjačka nacionalna zajednica za Grad Zagreb i Zagrebačku županiju.

- Kecman, Jovanka. 1978. Žene Jugoslavije u radničkom pokretu i ženskim organizacijama: 1918-1941. Beograd: Narodna knjiga - Institut za savremenu istoriju.

- Kemura, Ibrahim. 1986. Uloga "Gajreta” u društvenom životu Muslimana Bosne i Hercegovine (19031941). Sarajevo: Veselin Masleša.

- Konjhodžić, Mahmud. 1981. Mostarke: fragmenti o revolucionarnoj djelatnosti i patriotskoj opredjeljenosti žena Mostara, o njihovoj borbi za slobodu i socijalizam. Mostar: Opštinski odbor SUBNOR-a Mostar. 
- Mesić, Đurđa. 1991. "Narodna knjižnica - prilog određenju pojma" Journal of Information and Organizational Sciences 15: 145-159. https://hrcak.srce. hr/79913. Datum pristupa: 7. 10. 2019.

- Salahović-Grebo, Zlata. 2005. "Slavne Mostarke" Most: časopis za obrazovanje, nauku i kulturu 184(95). http://www.most.ba/095/014.aspx. Datum pristupa: 10. 4. 2019.

- Spahić, Aida. et al. 2014. Zabilježene: žene i javni život Bosne i Hercegovine u 20. vijeku. Sarajevo: Sarajevski otvoreni centar. http://soc.ba/site/wpcontent/uploads/2015/09/Zabiljezene_final-drugoizdanje_web_0909.pdf. Datum pristupa: 10.9.2019.
- $\quad$ Švenda-Radeljak, Ksenija. 2018. Obrazovanje i status knjižničara u Hrvatskoj do uvođenja studija bibliotekarstva. Zagreb: Pravni fakultet.

- Vučković, Željko. 2003. Javne biblioteke i javno znanje. Novi Sad: Biblioteka Matice srpske.

- Weibel, Kathleen, Kathleen M. Heim, i Dianne J. Ellswoth. 1979. The role of women in librarianship, 1876-1976: The entry, advancement, and struggle for equalization in one profession. Phoenix: Oryx Press.

\title{
THE IMPORTANCE OF PUBLIC LIBRARIES IN THE PROCESSES OF
} EMANCIPATION AND EMPOWERMENT OF WOMEN, AS EXEMPLIFIED BY THE WORK OF MUSLIM PUBLIC LIBRARY IN MOSTAR BETWEEN 1936 AND 1941

\begin{abstract}
In the first half of the 20th century, it was precisely the public libraries and reading rooms that have played an extremely important role in the processes of promoting progressive ideas and educating wide sections of society. Through their work these libraries have contributed to creating preconditions for the entire social and cultural transformation of Bosnia and Herzegovina's society. Among other things, public libraries have been important actors in the processes of women's empowerment, emancipation and education, and their reading rooms were often the only public space for sharing experiences and participating in socially beneficial activities. This paper presents activities that took place within the Muslim Public Library in Mostar from 1936 to 1941, enabling women not only to complete analphabetic courses but also to participate in the training and education of other women. Their engagement in the library has led many of them to become members of the anti-fascist resistance movement during the war and actively participate in the processes of post-war reconstruction and the building of a modern society of Bosnia and Herzegovina.
\end{abstract}

Keywords: public libraries, Muslim Public Library in Mostar, analphabetic courses, emancipation of women 